Research \& Learning in Nursing Science

\title{
PERBEDAAN EFEKTIFITAS KONSUMSI JUS SEMANGKA DAN JUS BELIMBING WULUH TERHADAP PENURUNAN TEKANAN DARAH PENDERITA HIPERTENSI DI WILAYAH KERJA PUSKESMAS BANGKINANG KOTA
}

\author{
Apriza \\ Program Studi Sarjana Keperawatan \\ Universitas Pahlawan Tuanku Tambusai \\ apriza@universitaspahlawan.ac.id
}

\begin{abstract}
Abstrak
WHO (2015) mencatat hampir 1 milyar diseluruh dunia memiliki tekanan darah tinggi, hipertensi merupakan salah satu penyebab utama kematian dini diseluruh dunia, ditahun 2020 sekitar 1,56 milyar orang dewasa akan hidup dengan hipertensi. Hipertensi membunuh hampir 8 milyar orang setiap tahunnya didunia dan hampir 1,5 juta orang setiap tahunnya berada di kawasan Asia Timur-Selatan. Sekitar sepertiga dari orang dewasa di Asia Timur-Selatan menderita hipertensi. Hipertensi menyebabkan bertambahnya beban kerja jantung dan menimbulkan kerusakan jantung dan pembuluh darah. Perubahan pola makan yang banyak mengandung kolesterol, protein, garam tinggi namun rendah serat pangan merupakan salah satu faktor risiko timbulnya hipertensi pada seseorang termasuk usia dewasa muda dan lansia. Penelitian dikembangkan untuk mendapatkan jenis terapi komplementer yang tepat untuk digunakan dalam menangani hipertensi. Beberapa tumbuhan obat yang potensial dan biasa digunakan masyarakat untuk menurunkan tekanan darah yaitu semangka dan belimbing wuluh. Tujuan penelitian ini untuk melihat perbedaan efektifitas jus semangka dan jus belimbing wuluh dalam menurunkan tekanan darah penderita hipertensi. Penelitian ini merupakan penelitian Quasi eksperiment dengan desain penelitian two group pretest post test desaign. Sampel penelitian ini adalah penderita hipertensi di wilayah Puskesmas Bangkinang Kota dengan responden sebanyak 30 orang yang diambil dengan cara purposive sampling. Hasil uji statistik yang digunakan adalah uji $T$ dua mean independen. Berdasarkan hasil uji $T$ dua mean independen di dapatkan bahwa nilai rata - rata penurunan tekanan darah setelah diberikan jus semangka sebesar 15,03 dan nilai rata - rata penurunan tekanan darah setelah diberikan jus belimbing wuluh sebesar 11,33 dengan nilai $\mathrm{p}=0,039<\alpha=0,05$, artinya ada perbedaan efektifitas jus semangka dan jus belimbing wuluh terhadap penurunan tekanan darah penderita hipertensi di Puskesmas Bangkinang Kota. Disarankan jus semangka sebagai salah satu alternatif bagi penderita hipertensi dalam menurukan hipertensi.
\end{abstract}

Kata Kunci : Jus semangka, Jus belimbing wuluh, Tekanan Darah

$\triangle$ Corresponding author :

Address : Jl. Tuanku Tambusai No 23 Bangkinang

Email : apriza@univeritaspahlawan.ac.id

Phone : 085211804568 


\section{PENDAHULUAN \\ Latar Belakang}

Hipertensi atau yang lebih dikenal dengan penyakit tekanan darah tinggi adalah suatu keadaan dimana seseorang mengalami peningkatan tekanan darah di atas normal yang ditunjukkan oleh angka sistolik (bagian atas) dan diastolik(bagian bawah) pada pemeriksaan tekanan darah menggunakan alat pengukur tekanan darah baik yang berupa cuff air raksa (sphygmomanometer) ataupun alat digital lainnya (Shadine, 2010).

Hipertensi merupakan salah satu penyakit paling mematikan di dunia. Sebanyak 1 milyar orang di dunia atau 1 dari 4 orang dewasa menderita penyakit ini. Hipertensi secara tidak langsung membunuh penderitanya, melainkan memicu terjadinya penyakit lain yang tergolong kelas berat dan mematikan serta member gejala yang berlanjut untuk organ tubuh, seperti stroke untuk otak, penyakit jantung koroner untuk pembuluh darah dan otot jantung (Komeliani dan Meida, 2012).

Menurut perkiraan WHO, sekitar 30\% penduduk dunia tidak terdiagnosa adanya hipertensi (underdiagnosed condition). Hal ini disebabkan oleh tidak adanya gejala yang pasti bagi penderita hipertensi padahal hipertensi merusak organ tubuh, seperti jantung (70\% penderita hipertensi akan mengalami kerusakan jantung), ginjal, otak, mata, serta organ tubuh lainnya. Kondisi tersebut yang menyebabkan hipertensi disebut sebagai pembunuh yang tidak terlihat atau silent killer ( Susilo\& Wulandari, 2010).

Saat ini hipertensi masih merupakan masalah yang cukup penting dalam pelayanan kesehatan. Hal ini dikarenakan angka prevalensi hipertensi yang cukup tinggi di Indonesia. Penyakit hipertensi telah menjadi masalah utama dalam kesehatan masyarakat yang ada di Indonesia maupun di beberapa negara yang ada di dunia.

Menurut Depkes RI (2008), hipertensi merupakan penyebab kematian nomor tiga setelah stroke $(15,4 \%)$, dan tuberkulosis $(7,5 \%)$, dengan dengan presentasi mencapai $6,8 \%$ dari populasi kematian pada semua umur di Indonesia ( Arif dkk, 2013).

Hipertensi merupakan penyebab utama stroke, penyakit jantung, dan gagal ginjal. Prognosisnya baik jika gangguan ini dideteksi sejak dini dan jika mulai ditangani sebelum pasien mengalami komplikasi. Tekanan darah yang naik dengan hebat (krisis hipertensi) bisa berakibat fatal (Williams \& Wilkins, 2011).

Pasien hipertensi di Provinsi Riau adalah $21,43 \%$ dari 662417 dari jumlah yang melakukan pengukuran tekanan darah (Munir, 2016). Data penderita di Kabupaten Kampar pada tahun 2017 jumlah penderita Hipertensi yaitu sebesar 24.251 orang. Berikut data hipertensi di 8 Puskesmas Kabupaten Kampar tahun 2017.

\subsection{Tabel Data Hipertensi di Kabupaten} Kampar

\begin{tabular}{clc}
\hline No & \multicolumn{1}{c}{ Puskemas } & Jumlah \\
\hline $\mathbf{1}$ & Kampar Timur & $\mathbf{2 9 9 4}$ \\
2 & Kampar & 1938 \\
3 & Kuok & 1814 \\
4 & Rumbio Jaya & 1307 \\
5 & Kampar Utara & 901 \\
6 & Bangkinang & 722 \\
7 & Bangkinang & 693 \\
& Seberang & \\
8 & Salo & 566 \\
\hline \multicolumn{2}{l}{ Sumber : Jumlah Penderita Hipertensi tahun } \\
2017
\end{tabular}

Berdasarkan tabel diatas dari 8 Puskesmas yang ada di Kabupaten Kampar Puskesmas Kampar Timur merupakan jumlah terbanyak Hipertensi yaitu sebanyak 2.994 orang.

Beberapa faktor resiko terjadinya hipertensi adalah perubahan pola makan yang banyak mengandung kolesterol, protein, garam tinggi namun rendah serat pangan. Kolesterol termasuk keluarga lemak, zat ini merupakan salah satu dari komponen lemak itu sendiri. Kehadiran lemak dalam tubuh memiliki fungsi sebagai zat gizi yang sangat diperlukan oleh tubuh disamping zat gizi lainnya seperti karbohidrat, protein, vitamin, dan mineral (Depkes RI, 2010)

Penyakit hipertensi dapat menyerang siapa saja, baik orang dewasa maupun lanjut usia. Hipertensi sering menyebabkan perubahan pada pembuluh darah yang dapat mengakibatkan semakin tingginya tekanan darah. Pengobatan awal pada hipertensi sangatlah penting karena dapat mencegah timbulnya komplikasi pada beberapa organ tubuh seperti jantung, ginjal, dan otak. Penyelidikan epidemiologis membuktikan bahwa tingginya tekanan darah berhubungan erat dengan morbiditas dan mortalitas penyakit kardiovaskuler ( Muttaqin, 2009).

Penanganan hipertensi bisa dilakukan secara farmakologi dan non formakologi. Pengobatan hipertensi dengan obat anti hipertensi bisa dilakukan melalui pengobatan medis dan bisa juga melalui pengobatan tradisional (secara alami) dengan menggunakan ramuan dari tanaman obat yang mempunyai efek menurunkan tekanan darah (Wijoyo, 2011).

Salah satu alternatif secara teori untuk penanganan dan pencegahan hipertensi dapat dilakukan dengan mengkonsumsi buah semangka. Kandungan yang ada dalam obat anti hipertensi tersebut ada beberapa yang kita temui dalam semangka yaitu potassium, beta karoten dan kalium. Dalam semangka sangat kaya akan 
kandungan air, asam amino, L-arginine dapat menjaga tekanan darah yang sehat (Nisa, 2012).

Penelitian Figueroa (dalam Nisa, 2012), mengatakan, bahwa kandungan asam amino semangka mampu meningkatkan fungsi arteri dan menurunkan tekanan darah pada aorta. Semangka dapat menurunkan tekanan darah tinggi karena likopen yang berfungsi untuk meningkatkan kerja jantung dan sitrulin yang mampu mendorong aliran darah ke seluruh bagian tubuh serta memberikan efek arfosidiak. Semangka mengandung banyak manfaat, seperti likopen yang mengandung zat antioksidan yang baik bagi kulit. Beta karoten yang baik bagi tubuh, vitamin B6 yang dapat merangsang hormone dalam otak untuk mengatasi kecemasan, vitamin $\mathrm{C}$ yang dapatmeningkatkan kekebalan tubuh serta vitamin A yang dapat melawan infeksi. Semangka juga mengandung protein, serat, arginin dan lain - lain.

Buahan lain yang diyakini bisa menurunkan tekanan darah adalah belimbing wuluh. Belimbing wuluh merupakan pengobatan tradisional dan non medis yang dapat digunakan oleh masyarakat untuk menurunkan tekanan darah.

Buah belimbing wuluh matang bersifat asam dan tinggi kandungan serat dan mineral seperti kalsium, fosfor, zat besi, dan kalium. Selain itu, buah belimbing wuluh juga mengandung senyawa kimia yaitu asam format, asam sitrat, asam askorbat (Vitamin C), saponin, tanin, flavonoid, dan glukosid. Senyawa vitamin C, kalium, flavonoid. Saponin dalam belimbing wuluh diduga kuat dapat menurunkan tekanan darah. Vitamin C telah diakui sebagai antioksidan vasodilator kuat yang mengurangi stres oksidatif dan meningkatkan fungsi endotel melalui produksi nitrat oksida.

Konsentrasi kalium yang tinggi dalam cairan intraselular dapat merelaksasi sel otot polos pembuluh darah, kemudian dapat mengurangi resistensi pembuluh darah perifer sehingga dapat menurunkan tekanan darah. Flavonoid akan mempengaruhi kerja dari Angiotensin Converting Enzyme (ACE). Penghambatan ACE akan menginhibisi perubahan angiotensin I menjadi angiotensin II yang menyebabkan vasodilatasi sehingga tahanan resistensi perifer turun dan dapat menurunkan tekanan darah. Saponin memiliki khasiat diuretik dengan menurunkan volume plasma dengan cara mengeluarkan air dan elektrolit terutama natrium sehingga dapat menyebabkan penurunan cardiac output.

Pada penelitian Ihsan (2012) , ekstrak belimbing wuluh dapat menurunkan tekanan darah tikus wistar (Rattus norvegicus) dari kondisi hipertensi menjadi normotensi setelah pemberian selama 2 minggu dengan dosis $40 \mathrm{~g} / \mathrm{kg}$ BB.19 Selain itu, pemberian jus belimbing wuluh sebanyak $250 \mathrm{ml}$ dapat menurunkan tekanan darah normal pada wanita dewasa dari 107,17/72,67
mmHg menjadi 94,27/65,80 $\mathrm{mmHg}$ dengan penurunan yang signifikan $(\mathrm{p}<0,01)$.

Dari penelitian diatas belum jelas penanganan yang mana yang lebih efektif dalam menurunkan tekanan darah pada penderita hipertensi. Peneliti ingin melihat perbedaan efektifitas penurunan tekanan darah pada penderita hipertensi pada dua kelompok yang diberikan perlakuan pemberian minuman jus semangka dan jus belimbing wuluh.

\section{Rumusan Masalah}

Prevalensi hipertensi dari tahun ketahun semakin meningkat. Data menunjukkan beberapa tahun terakhir, hipertensi menduduki peringkat kedua dari 10 penyakit terbesar di Kabupaten Kampar. Ada peningkatan jumlah pasien hipertensi pada tahun 2017, dari total populasi> 15 tahun di wilayah kerja Pusat Kesehatan Distrik Kampar dari 555.098 orang yang diukur 154.571 orang, dari total tekanan darah diukur 54.369 orang yang mengalami hipertensi / darah tinggi tekanan. Dengan pasien wanita sebanyak 29.032 orang dan 25.337 pria berjenis kelamin pria (Nurbit, 2017) Berbagai studi yang berbasiskan populasi telah dilakukan untuk mengidentifikasi berbagai penanganan hipertensi. Penelitian untuk meneliti tanaman obat yang bisa menurunkan tekanan darah penderita hipertensi sebagai solusi yang dapat digunakan oleh masyarakat. Penelitian tentang tanaman buah semangka dan belimbing wuluh menjadi pilihan dalam penelitian ini. Hal yang terpenting adalah masyarakat mengetahui bahwa mana yang lebih efektif dalam menurunkan tekanan darah pada penderita hipertensi. Dengan demikian, masalah penelitian ini adalah perbedaan efektifitas jus semangka dan jus belimbing wuluh dalam menurunkan tekanan darah pada penderita hipertensi.

A. Pertanyaan Penelitian

Bagaimanakah perbedaan efektifitas jus semangka dan jus belimbing wuluh dalam menurunkan tekanan darah pada penderita hipertensi di kabupaten Kampar?

B. Tujuan penelitian

Tujuan umum penelitian adalah untuk mengetahui efektifitas konsumsi jus semangka dan jus belimbing wuluh dalam menurunkan tekanan darah pada penderita hipertensi.

Tujuan khusus adalah :

a. Untuk mengetahui distribusi frekuensi tekanan darah pada penderita hipertensi sebelum pemberian jus semangka.

b. Untuk mengetahui distribusi frekuensi tekanan darah pada penderita hipertensi setelah pemberian jus semangka. 
c. Menganalisis pengaruh pemberian jus semangka terhadap penurunan tekanan darah pada penderita hipertensi

d. Mengetahui rata-rata penurunan tekanan darah dengan pemberian jus semangka

e. Untuk mengetahui distribusi frekuensi tekanan darah pada penderita hipertensi sebelum pemberian jus belimbing wuluh

f. Untuk mengetahui distribusi frekuensi tekanan darah pada penderita hipertensi setelah pemberian jus belimbing wuluh

g. Menganalisis pengaruh pemberian jus belimbing wuluh terhadap penurunan tekanan darah pada penderita hipertensi

h. Mengetahui rata-rata penurunan tekanan darah dengan pemberian jus belimbing wuluh

i. Mengetahui efektifitas minuman jus semangka dan jus belimbing wuluh

C. Manfaat penelitian

1. Penelitian bisa memberikan informasi tentang terapi non farmakologi yang bisa digunakan dalam nenurunkan tekanan darah pada penderita hipertensi dan bisa diaplikasikan langsung dimasyarakat.

2. Penelitian diharapkan dapat digunakan sebagai dasar untuk menyusun berbagai jenis terapi yang dapat berkontribusi dalam menurunkan prevalensi hipertensi di Kabupaten Kampar.

\section{METODE PENELITIAN}

A. Metode penelitian

Penelitian ini menggunakan rancangan penelitian Quasi Eksperimental Design, dengan rancangan penelitian yang digunakan adalah Two Group Pre Test and Post Test Design artinya sampel pada penelitian ini diobservasi terlebih dahulu sebelum diberi perlakuan, kemudian setelah diberi perlakuan sampel tersebut diobservasi kembali.

B. Tempat dan Waktu Penelitian

Penelitian dilakukan pada bulan Januari Maret 2019 di kelurahan Bangkinang.

C. Populasi dan Sampel

1. Populasi dalam penelitian ini adalah penderita hipertensi di kelurahan Bangkinang berjumlah 722 orang.

2. Sampel adalah bagian dari populasi yang diteliti (Hidayat, 2007). Sampel pada penelitian ini yaitu penderita hipertensi di kelurahan Bangkinang sebanyak 20 responden dan sesuai dengan kriteria inklusi dan eklusi sampel.

D. Instrumen pengumpulan data

Pengumpulan data digunakan pada penelitian ini menggunakan kuisoner dan observasi menggunakan data primer dan pengolahan data menggunakan komputerisasi. Analisis data yang digunakan pada penelitian ini adalah dengan menggunakan uji $T$ dua mean independen untuk menguji perbedaan mean antara 2 kelompok data independen dengan batas derajad kemaknaan $\alpha 5 \%(\alpha=0,05)$.

E. Bahan dan prosedur pengumpulan data:

1) Bahan dan Alat

Bahan yang digunakan dalam penelitian berupa alat pengukur tensi, blender, alat ukur dan lembar observasi checklist dan lembar wawancara tentang data demografi, karakteristik responden.

2) Prosedur pengumpulan data yaitu:

a. Peneliti mengurus surat permohonan izin pengambilan data ke Lembaga Penelitian Universitas Pahlawan Tuanku Tambusai

b. Surat izin pengambilan data diteruskan kepada kepala Puskesmas Bangkinang Kota

c. Eksplorasi informasi tentang data penderita hipertensi di wilayah kerja puskesmas Bangkinang Kota

d. Permohonan izin melakukan penelitian di Puskesmas Bangkinang Kota ke lembaga penelitian Universitas pahlawan Tuanku Tambusai

e. Meneruskan surat izin melakukan penelitian kepada kepala Puskesmas Bangkinang Kota

f. Melakukan teknik pengambilan sample secara purposive sampling dari data yang telah didapatkan serta menentukan kriteria inklusi dan ekslusi sampel.

g. Turun kelapangan untuk melakukan penelitian. Tahapan orientasi yaitu perkenalan, penyampaian tujuan, manfaat dan bentuk kegiatan penelitian yang akan dilakukan kepada responden. Selanjutnya meminta persetujuan untuk menjadi 
responden bagi terpilih untuk menjadi sampel.

h. Melakukan pengamatan, intervensi dan wawancara sesuai dengan instrument yang telah disusun

i. Mengolah data yang telah diperoleh.

F. Izin Penelitian

Diawali dengan memasukkan surat permohonan untuk melakukan penelitian ke Lembaga Penelitian Universitas Pahlawan Tuanku Tambusai. Selanjutnya surat yang telah dikeluarkan oleh LP diteruskan ke Puskesmas Bangkinang Kota guna mendapatkan izin melakukan penelitian diwilayah kerja puskesmas Bangkinang Kota.

G. Pengolahan data

Pengolahan data yang telah diperoleh sebagai berikut: a) Editing, Berfungsi untuk meneliti kelengkapan data diantaranya kelengkapan identitas responden, kelengkapan lembar observasi dan wawancara yang dilakukan ditempat pengambilan data sehingga bila terdapat ketidaksesuaian dapat dilengkapi dengan segera. b) Coding, Mengklasifikasikan data yang diperoleh dengan cara menandai masing-masing jawaban dengan kode berupa angka, kemudian dimasukkan kedalam lembar tabel kerja guna mempermudah membacanya dan pengolahan data. 3) Skoring (penilaian) Pada tahap ini peneliti memberi nilai pada data sesuai dengan skor yang telah ditentukan . 4) Data entry (memasukkan data) tahap terakhir dalam penelitian ini yaitu pemprosesan data, yang dilakukan oleh peneliti adalah memasukkan data dari lembar observasi dan wawancara kedalam paket program komputer. 5) Tabulating, memasukkan data hasil penilitian kedalam tabel sesuai kriteria untuk bisa mendapatkan hasil gambaran sanitasi lingkungan rumah responden dengan menggunakan komputerisasi SPSS

H. Analisa data

Analisa data yang akan digunakan dalam penelitian ini yaitu analisa data univariat. Untuk mendapatkan gambaran tentang persentase tekanan darah sebelum dan sesudah perlakuan. Untuk mendapatkan persentase dari tiap variabel menggunakan rumus distribusi frekuensi sebagai berikut:

$$
\begin{aligned}
& P=\frac{f}{\mathrm{~N}} \times 100 \% \\
& \text { Keterangan: } \\
& \mathrm{P}=\text { Besar presentase alternatif } \\
& \text { jawaban }
\end{aligned}
$$

$$
\begin{array}{ll}
\mathrm{f} & =\text { frekuensi } \\
\mathrm{N} & =\text { seluruh observasi }
\end{array}
$$

Sedangkan Analisis data bivariate yang digunakan adalah dengan menggunakan uji $T$ dua mean independen untuk menguji perbedaan mean antara 2 kelompok data independen dengan batas derajad kemaknaan $\alpha \quad 5 \%(\alpha=0,05)$.

\section{BAB IV HASIL PENELITIAN}

Bab ini menyajikan mengenai hasil penelitian tentang perbedaan efektifitas jus semangka dan jus belimbing wuluh terhadap penurunan tekanan darah penderita hipertensi di Bangkinang Kota Kabupaten Kampar. Penelitian mulai dilaksanakan pada bulan Januari 2020 dengan populasi adalah penderita hipertensi pada Januari-Maret 2020 yang bertempat tinggal di Kelurahan Bangkinang wilayah kerja Puskesmas Bangkinang Kota. Sampel pada penelitian ini adalah penderita hipertensi yang sesuai dengan kriteria inklusi dan ekslusi yang telah ditentukan dan bertempat tinggal di wilayah kerja Puskesmas Bangkinang Kota. Pada penelitian ini digunakan teknik pengambilan sampel secara purposive sampling dengan jumlah sampel sejumlah 20 orang.

Dalam pelaksanaan penelitian ini menggunakan instrument lembar checklist untuk menginput nilai tekanann darah penderita. Wawancara untuk mengetahui data demografi berupa; umur, jenis kelamin, pekerjaan, dan kondisi penderita. Data primer diperoleh ketika peneliti turun langsung untuk melakukan observasi ke rumah penderita dengan mengisi lembar checklist yang telah disiapkan. Data sekunder diperoleh dari puskesmas kuok berdasarakan medical record penderita.

Dalam pelaksanaan penelitian bulan Januari 2020, peneliti melakukan pengumpulan data dengan melakukan intervensi langsung dengan membagi responden kedalam dua kelompok yang terdiri dari 10 responden untuk perlakuan pemberian jus semangka dan 10 responden lagi untuk pemberian perlakuan jus belimbing wuluh. Peneliti juga melakukan wawancara untuk mengetahui data demografi berupa; umur, jenis kelamin, pekerjaan, dan kondisi penderita tanpa memberikan perlakuan pada objek penelitian.

\section{Tabel 4.1}

Perbandingan Nilai Tekanan Darah Penderita Hipertensi Sebelum dan Sesudah Diberikan jus semangka pada penderita Hipertensi Di Kelurahan Bangkinang Wilayah Kerja Puskesmas Bangkinang Kota

\begin{tabular}{ccccccc}
\hline No Variabel Penguku Mean & SD & \multicolumn{1}{c}{$\begin{array}{c}\text { Min- } \\
\text { Man }\end{array}$} & $\begin{array}{c}\text { P } \\
\text { Value }\end{array}$ \\
\hline $\mathbf{1}$ & Tekanan & Sebelum & 149 & 8.755 & $120-$ & 0,03 \\
& Darah & Sesudah & 131 & 8.755 & 140 & \\
& Sistolik & & & & & \\
2 & Tekanan & Sebelum & 89 & 7,378 & $70-$ & 0,02 \\
\hline
\end{tabular}




\begin{tabular}{ccccc}
\hline Darah & Sesudah & 78 & 6.324 & 90 \\
Diastolik & & & & \\
\hline
\end{tabular}

Dari tabel 4.1 dapat di lihat bahwa rata-rata tekanan darah sistolik sebelum dilakukan intervensi adalah $149 \mathrm{mmHg}$ dengan standar deviasi 8.755. Pada pengukuran tekanan darah sistolik sesudah dilakukan intervensi didapat ratarata tekanan darah sistolik adalah $131 \mathrm{mmHg}$ dengan standar deviasi 8.755

Rata-rata tekanan darah diastolik sebelum dilakukan intervensi adalah $89 \mathrm{mmHg}$ dengan standar deviasi 7.378. Pada pengukuran tekanan darah diastolik sesudah dilakukan intervensi didapat rata-rata tekanan darah diastolik adalah 78 mmHg dengan standar deviasi 6.324.

Hasil uji statistik didapatkan nilai $\mathrm{p}$ value adalah 0,03 . Apabila dibandingkan dengan nilai $\alpha$ maka nilai $\mathrm{p}=0,00<\alpha=0,05$ yang menunjukkan bahwa ada perbedaan yang signifikan antara pengukuran tekanan darah sistolik dan diastolik sebelum dan sesudah dilakukan intervensi

Tabel 4.2

Perbedaan Rata-Rata Tekanan Darah Sebelum Dan Sesudah Diberikan Jus Belimbing wuluh pada penderita Hipertensi Di Kelurahan Bangkinang Wilayah Kerja Puskesmas Bangkinang Kota

\begin{tabular}{ccccccc}
\hline No Variabel Penguku & Mean & SD & \multicolumn{1}{c}{$\begin{array}{c}\text { Min- P } \\
\text { ran }\end{array}$} & & & $\begin{array}{l}\text { Max } \\
\text { Value }\end{array}$ \\
\hline 1 & Tekanan & Sebelum & 161.67 & 17.237 & $140-$ & 0,00 \\
Darah & & & & 170 & \\
& Sistolik & Sesudah & 143.67 & 18.659 & & \\
2 & Tekanan & Sebelum & 101.16 & 11.254 & $80-$ & 0,00 \\
Darah & Sesudah & 85.24 & 87.023 & 110 & \\
& Diastolik & & & & & \\
\hline
\end{tabular}

Dari tabel 4.2 dapat di lihat bahwa rata-rata tekanan darah sistolik sebelum dilakukan intervensi adalah $161.67 \mathrm{mmHg}$ dengan standar deviasi 17.237. Pada pengukuran tekanan darah sistolik sesudah dilakukan intervensi didapat ratarata tekanan darah sistolik adalah $143.67 \mathrm{mmHg}$ dengan standar deviasi 11.254.

Rata-rata tekanan darah diastolik sebelum dilakukan intervensi adalah $101.16 \mathrm{mmHg}$ dengan standar deviasi 11.254. Pada pengukuran tekanan darah diastolik sesudah dilakukan intervensi didapat rata-rata tekanan darah diastolik adalah $85.24 \mathrm{mmHg}$ dengan standar deviasi 87.023

\section{BAB V PEMBAHASAN}

Berdasarkan Penelitian sebelumnya yang dilakukan oleh Michelle Angelina Tanuwijaya (2012) menjelaskan bahwa dengan pemberian jus semangka sekali sehari selama 1 minggu bisa menurunkan tekanan darah pada penderita hipertensi. Hasil analisis pada penelitian ini menunjukkan bahwa rata-rata tekanan darah sebelum 115,68/73,23 mmHg untuk tekanan darah sistolik dan $110,67 / 70,32 \mathrm{mmHg}$ untuk tekanan darah diastolik.

Mekanisme buah semangka dalam menurunkan tekanan darah beragam karena kandungan nutriennya, antara lain asam amino arginine, karotenoid dan citruline yang merupakan precusor utama pembentukan Nitrit Oksida (NO), kalium, serta kandungan air yang tinggi (Dalimartha, 2007; Suhardi, 2009; Sekarninsih \& Rozaline 2006).

Salah satu faktor yang mempengaruhi tekanan darah adalah resistensi perifer. Resistensi perifer adalah gabungan resistensi pada pembuluh darah (arteri dan arteriol) dan viskositas darah . Kandungan buah semangka yang bekerja pada bagian ini adalah asam amino agrninine dan citruline. Citrulline adalah asam amino nonesensial yang berfungsi sebagai precursor untuk nitrik Oksida. Nitrit Oksida (NO) sendiri merupakan substansi dilator umum pendek yang dilepaskan oleh sel endotel pembuluh darah dalam responnya terhadap pengikatan vasodilator pada reseptor sel endotalium (Rodwall, 2009).

Hasil penelitian yang peneliti lakukan dengan memberikan 200 gram daging semangka ditambah $50 \mathrm{cc}$ air/hari selama 7 hari, didapatkan rata-rata penurunan tekanan darah sistolik dan diastolik pada penderita hipertensi adalah $18 \mathrm{mmHg}$ untuk tekanan darah sistolik dan $11 \mathrm{mmHg}$ untuk tekanan darah diastolik. Hal ini menunjukkan bahwa pemberian 200 gram daging semangka perhari berpengaruh dalam menurunkan tekanan darah pada penderita hipertensi. Penurunan tekanan darah tersebut disebabkan oleh senyawa kimia yang terkandung didalam semangka diantaranya yaitu asam amino arginine, karotenoid dan citruline.

Kandungan yang ada dalam obat anti hipertensi dan dapat kita temui dalam semangka yaitu potassium, beta karoten dan kalium. Dalam semangka sangat kaya akan kandungan air, asam amino, L-arginine dapat menjaga tekanan darah yang sehat (Nisa, 2012).

Penelitian Figueroa (dalam Nisa, 2012), mengatakan, bahwa kandungan asam amino semangka mampu meningkatkan fungsi arteri dan menurunkan tekanan darah pada aorta. Semangka dapat menurunkan tekanan darah tinggi karena likopen yang berfungsi untuk meningkatkan kerja jantung dan sitrulin yang mampu mendorong aliran darah ke seluruh bagian tubuh serta memberikan efek arfosidiak. Semangka mengandung banyak manfaat, seperti likopen yang mengandung zat antioksidan yang baik bagi kulit. Beta karoten yang baik bagi tubuh, vitamin B6 yang dapat merangsang hormone dalam otak untuk mengatasi kecemasan, vitamin $\mathrm{C}$ yang dapatmeningkatkan kekebalan tubuh serta vitamin 
A yang dapat melawan infeksi. Semangka juga mengandung protein, serat, arginin dan lain - lain. Dari hasil penelitian tersebut dapat disimpulkan bahwa pemberian jus semangka secara teratur sejumlah 200 gram/hari selama 7 hari dapat menurunkan tekanan darah pada penderita hipertensi

Pada penelitian ini juga dilakukan intervensi pemberian jus belimbing wuluh sebanyak 200 gram/hari, selama 7 hari pada penderita hipertensi. Pada penelitian ini responden mengalami penurunan tekanan darah yang cukup signiufikan yaitu dilihat dari nilai meannya, untuk penurunan tekanan darah sistolik pada responden yang diberika diberikan jus belimbing wuluh sebesar $18 \mathrm{mmhg}$ dan tekanan darah diastolik sebesar 13 $\mathrm{mmHg}$ yang artinya jus belimbing wuluh efektif menurunkan tekanan darah.

Belimbing wuluh mengandung golongan senyawa oksalat, minyak menguap, fenol, flavonoid dan pektin dan dapat menurunkan tekanan darah tinggi pada penderita hipertensi. Buah yang mengandung senyawa flavonoid tersebut memang sangat dianjurkan untuk dikongsumsi oleh penderita hipertensi.

Hasil penelitian ini juga didukung oleh penelitian Nidya Putri Ihsan (2013) Pengaruh Belimbing Wuluh (Averrhoa Bilimbi L.) Terhadap Penurunan Tekanan Darah. Penelitian ini dilakukan pada 30 orang pria dewasa usia 18-28 tahun, dilakukan pengukuran tekanan darah sistol dan diastol dalam satuan $\mathrm{mmHg}$ setelah dan sebelum mengonsumsi $250 \mathrm{ml}$ jus belimbing wuluh. Hasil percobaan menunjukkan bahwa rerata tekanan darah sesudah mengonsumsi belimbing wuluh sebesar 111,50/77,67 $\mathrm{mmHg}$ lebih rendah dibandingkan tekanan darah rerata sebelum mengonsumsi belimbing wuluh yaitu sebesar 120,53/82,03 mmHg $(\mathrm{p}<0,01)$.

Menurut asumsi peneliti mengkonsumsi belimbing wuluh dapat dijadikan sebagai terapi non farmakologi untuk menurunkan tekanan darah dan belimbing wuluh mudah ditemukan, murah serta cara mengelolahnya pun sangat mudah kemudian pada saat penelitian tekanan darah penderita hipertensi sangat bervariasi antara satu dengan yang lainnya dan pada penelitian ini sebagian besar penderita hipertensi berada pada rentang umur 45-55 tahun hal ini mungkin disebabkan karena semakin berkurangnya distensibilitas dinding pembuluh darah seiring pertambahan usia sehingga dapat mengakibatkan peningkatan terhadap tekanan sistolik dan diastolik dan pada jenis kelamin yang terbanyak adalah perempuan, hal ini disebabkan karena perempuan memiliki hormon estrogen dan progesteron yang menjaga pembuluh darah tetap elastis, tetapi setelah menopause, tekanan darah akan meningkat karena pembuluh darah menjadi tidak elastis lagi.
Dalam penelitian ini tekanan darah responden diukur pada hari ke 1 sebelum berikan jus belimbing wuluh dan setelah diberikan jus belimbing wuluh selama 7 hari maka tekanan darah diukur pada hari ke 8 , kemudian dihitung nilai perbandingan antara tekanan darah sebelum dan sesudah diberikan jus belimbing wuluh. Hal ini membuktikan bahwa pemberian jus belimbing wuluh berpengaruh terhadap penurunan tekanan darah karena terdapat perbedaan yang signifikan pada tekanan darah penderita hipertensi tersebut.

Perbandingan antara pemberian jus semangka dan jus belimbing wuluh dalam penelitian ini memperoleh hasil yang relatif sedikit berbeda. Meskipun pada dasarnya jus semangka dan jus belimbing wuluh sama sama mampu menurunkan tekanan darah pada penderita. Hasil penelitian menunjukkan bahwa pada perlakuan pemberian jus semangka mampu menurunkan tekanan darah sebesar $18 \mathrm{mmHg}$ pada sistolik dan $11 \mathrm{mmHg}$ pada diastolik, sedangkan pada intervensi pemberian jus belimbing wuluh menurunkan tekanan darah sistolik sebesar $18 \mathrm{mmHg}$ dan 13 $\mathrm{mmHg}$ pada diastolik. Dari hasil ini dapat dilihat bahwa jus belimbing wuluh lebih efektif digunakan dalam menurunkan tekanan darah dibandingkan dengan jus semangka.

\section{BAB VI Simpulan dan saran}

\section{Simpulan}

Dari hasil penelitian ini dapat dilihat bahwa pemberian jus belimbing wuluh lebih efektif dalam menurunkan tekanan darah pada penderita hipertensi.

2. Saran

Diharapkan kepada instansi pelayanan kesehatan dapat mensosialisasikan kepada penderita hipertensi agar bisa menggunakan terapi jus belimbing wuluh dalam menurunkan tekanan darah sesuai dengan dosis yang dianjurkan.

\section{DAFTAR PUSTAKA}

Annisa (2016) Pengaruh Pemberian Sari Buah Belimbing Wuluh (Averrhoa Bilimbi L.) Terhadap Tekanan Darah Sistolik Remaja.Semarang. Diakses pada tanggal 2 maret 2018

Anne Ahira (2015). Penatalaksanaan Jus Semangka. Diperoleh tanggal 28 Juli 2015 dari http:// (www.blogspot.com).

Anderson. (2006). Hipertensi. Diperoleh tanggal 08 Mei 2015 dari http:// (www.blogspot.com).

A.P.Bangun. (2015). Terapi Hipertensi. Diperoleh tanggal 27 Mei 2015 dari http:// (www.blogspot.com).

Ari (2016) Jus Sehat. Bandung. Diakses pada tanggal 02 Maret 2018 
Arjatmo, Hendra. (2015). Pengobatan Hipertensi. Diperoleh tanggal 5 Mei 2015 dari http:// (www.blogspot.com).

Arturo. (2012). Tanaman Herbal. Diperoleh tanggal 06 Juni 2015 dari http:// (www.blogspot.com).

Bambang, Sadewo. (2015). Pencegahan Hipertensi. Diperoleh tanggal 21 Maret 2015 dari http:// (www.blogspot.com).

Brunner dan Suddarth. (2002). Buku Ajar Keperawatan Medical Bedah. Jakarta: EGC.

Bustan (2015) Penyakit yang tidak menular. Jakarta: Rineka Cipta

Data Nutrisi USDA. (2015). Kandungan Buah Semangka. Diperoleh 17 Juli 2015 dari http:// (www.blogspot.com).

Depkes, RI. (2014). Profil Kesehatan Indonesia. Tahun 2014.

Depkes R1 (2014). Hipertensi dan Penanganannya. Jakarta. Diakses pada tanggal 10 mei 2018

Dinkes, Riau. (2014). Profil Kesehatan Indonesia. Tahun 2014.

Dinas Kesehatan Kabupaten Kampar (2018) Jumlah penyakit terbesar dikabupaten kampar. Bangkinang

Dinkes, Kab. Kampar (2014). Profil Kesehatan kabupaten Kampar. Tahun 2014.

Dony, Wicaksono. (2013). Bertanam Semangka. Jakarta: Penebar Swadaya.

Dirjen P2TPM (2015). Penyakit Hipertensi di Indonesia. Jakarta. Diakses pada tanggal 10 Februari 2018

Elizabeth J.Corwin. (2009). Jilid Pertama. Jakarta: Media Aesculapius.

Fatimah (2010). Penggunaan Jus belimbing Wuluh. Diakses pada tanggal 10 Maret 2018

Hery Soeryoko. (2010). Bentuk-Bentuk Sajian Herbal Untuk Hipertensi.Yogkarta: C.V Andi offset.

Hidayat (2008). Riset Keperawatan dan Teknik Penulisan Ilmiah. Jakarta : Salemba Medika.

Iip Dkk (2010). Efektifitas Jus Belimbing Terhadap Penurunan Tekanan Darah Pada Lansia Di Kelurahan Tawangmas Baru Kecamatan Semarang Barat. Diakses pada tanggal 23 februari 2018

Ikhwan (2009). Struktur komposisi belimbing wuluh. Diakses pada tanggal 01 April 2018

Ihsan (2012). Ekstrak belimbing Wuluh. Diakses pada tanggal 12 Maret 2018

Kemenkes (2014). Jumlah Penderita Hipertensi Di Indoensia. Jakarta diakses pada tanggal 10 maret 2018

Komeiliani \& Meida. (2012). Hipertensi. Diperoleh tanggal 11 juli 2015 dari http://id.wikipedia.org/wiki/hipertensi.
Lilyasari dkk (2010). Tekanan darah tinggi dan manifestasinya. Diakses pada tanggal 10 Maret 2018

Masruhen (2009) Pengaruh Pemberian Infus Buah Belimbing Wuluh (Averrhoa bilimbi L.) Terhadap Kadar Kolesterol Darah Tikus. Diakses pada tanggal 1 Maret 2018

Nidia Putri Ihsan (2013). Pengaruh Belimbing Wuluh (Averrhoa Bilimbi L.) Terhadap Penurunan Tekanan Darah. Diakses pada tanggal 2 april 2018

Notoatmdjo (2010). Metodologi Penelitian.Kesehatan Jakarta : Rineka Cipta

Nurhaedar (2010). Hipertensi. Makasar diakses pada tanggal 1 mei 2018

Riskesdas (2013). Jumlah pederita hipertensi. Diakses pada tanggal 20 maret 2018

(2015). Jumlah penderita hipertensi di Propinsi Riau. Diakses pada tanggal 3 maret 2018

Roktaeni (2011). Manifestasi Klinis Hipertensi. Diakses pada tanggal 21 Maret 2018

Shadine. (2010). Definisi Hipertensi. Jakarta: Pustaka Sinar Harapan.

Susilo\&Wulandari. (2010). Prevalensi Hipertensi. Jakarta: EGC.

Udjianti (2010). Keperawatan Kardiovaskuler. Jakarta: Salemba Medika

Hendra. (2013). Manfaat buah semangka. Diperoleh tanggal 21 Mei 2015 dari http:// (www.blogspot.com).

Human Capital investment. Diperoleh tanggal 28 Juni 2015 dari http:// (www.worldpress.com). 